Leszek Wroński

Reichenbach's Paradise

Constructing the Realm of Probabilistic Common "Causes" 



\section{Leszek Wroński}

Reichenbach's Paradise

Constructing the Realm

\section{of Probabilistic Common "Causes"}

Managing Editor: Anna Michalska

Language Editor: Sara Tavares 
Published by De Gruyter Open Ltd, Warsaw/Berlin

\section{$($ Ba) Br-NC-ND}

This work is licensed under the Creative Commons Attribution-NonCommercial-NoDerivs 3.0 license, which means that the text may be used for non-commercial purposes, provided credit is given to the author. For details go to http://creativecommons.org/licenses/by-nc-nd/3.0/.

Copyright @ 2014 Leszek Wroński

ISBN 978-3-11-037270-0

e-ISBN 978-3-11-037271-7

\section{Bibliographic information published by the Deutsche Nationalbibliothek}

The Deutsche Nationalbibliothek lists this publication in the Deutsche Nationalbibliografie; detailed bibliographic data are available in the Internet at http://dnb.dnb.de.

Managing Editor: Anna Michalska

Language Editor: Sara Tavares

www.degruyteropen.com

Cover illustration: @ IStock/VikaSuh 
To my parents 